Yayınlayan: Ankara Üniversitesi KASAUM

Adres: Kadın Sorunları Araştırma ve Uygulama Merkezi, Cebeci 06590 Ankara

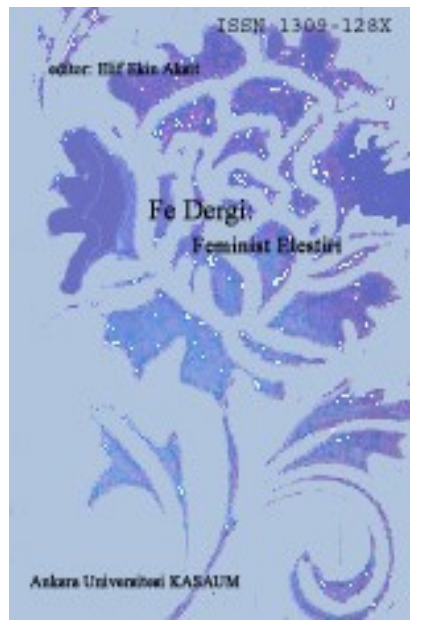

Fe Dergi: Feminist Eleştiri 13, Sayı 1

Erişim bilgileri, makale sunumu ve ayrıntılar için:

http://cins.ankara.edu.tr/

Ahmet Ümit'in “Overlokçu Koz” Başlıklı Hikâyesinde

Toplumsal Cinsiyet İlişkileri ve Erkeklik Temsilleri

Saniye Çancı Çalışaneller

Çevrimiçi yayına başlama tarihi: 10 Haziran 2021

Yazı Gönderim Tarihi: 09.09.2020

Yaz1 Kabul Tarihi: 05.03.2021

Bu makaleyi alıntılamak için: Saniye Çancı Çalışaneller, "Ahmet Ümit'in "Overlokçu Kız" Başlıkı Hikâyesinde Toplumsal Cinsiyet İlişkileri ve Erkeklik Temsilleri” Fe Dergi 13, no. 1 (2021), 16-27.

URL: http://cins.ankara.edu.tr/25_2.pdf

Bu eser akademik faaliyetlerde ve referans verilerek kullanılabilir. Hiçbir şekilde izin alınmaksızın çoğaltılamaz. 


\title{
Ahmet Ümit’in “Overlokçu Kız” Başlıklı Hikâyesinde Toplumsal Cinsiyet İlişkileri ve Erkeklik Temsilleri Saniye Çancı Çalışaneller*
}

\begin{abstract}
Bu çalışmanın amacı Ahmet Ümit’in 2019 yılında yayımlanan Aşkımız Eski Bir Roman başlıklı kitabındaki "Overlokçu Kız" hikâyesini toplumsal cinsiyet ilişkilerinin temsilleri bağlamında incelemektir. Eşitsiz toplumsal cinsiyet ilişkileri aynı gerçek dünyada olduğu gibi bu hikâyedeki kurmaca evrenin de her katmanina nüfuz ettiği için "Overlokçu Kız" toplumsal cinsiyet politikalarının nasıl işlediğini anlamlandırmak ve tartışmak adına yerinde bir örnek teşkil edecektir. Çalışma, toplumsal cinsiyet ve erkeklikler ile ilgili tartışmalar ışığında, hikâyenin karakterlerine odaklanarak eşitsiz toplumsal cinsiyet ilişkilerinin değişik bağlamlarda ve kültürel süreçlerde ataerkil sistemi inşa eden örüntülerine dikkat çeker. Bunun yanı sıra, karakterlerin birbirleriyle olan ilişkilerine odaklanarak, erkek egemen toplumda kadınlar ve erkekler arasındaki iktidar ilişkilerini sorgular ve aynı zamanda farklı erkeklikler arasındaki iktidar ilişkilerini de mercek altına alır. Bu anlamda çalışma eşit olmayan toplumsal cinsiyet yapılarının inşa süreçlerini hem kadınlar ve erkekler arasındaki ilişkiler hem de farklı erkekliklerin birbirleriyle olan etkileşimleri bă̆lamında tartışır.
\end{abstract}

Anahtar Kelimeler: Ahmet Ümit, “Overlokçu Kız,” toplumsal cinsiyet, erkeklikler, ataerki

\section{The Representation of Gender Relations and Masculinities in Ahmet Ümit's “Overlokçu Kız”}

The aim of this paper is to analyze the representation of gender relations and masculinities in Ahmet Ümit's “Overlokçu Kız," a short story in Ümit's book titled Aşkımız Eski Bir Roman published in 2019. "Overlokçu Klz" is a notable example to discuss gender politics because, as in real life, unequal gender relations pervade every single aspect of this fictional universe by shedding lights on the ways in which the unequal gender structure is constructed. In light of discussions surrounding the topics of gender and masculinities, this paper focusing on the characters in the story scrutinizes unequal gender relations in different contexts and cultural processes that contribute to the construction of patriarchy throughout the story. The paper also questions the power structures and relations between women and men and among masculinities. In this context, it discusses the ways in which the unequal gender structure is constructed in connection with the relationship between women and men along with the interactions among masculinities.

Keywords: Ahmet Ümit, “Overlokçu Klz,” gender, masculinities, patriarchy

Giriş

Ahmet Ümit'in “Overlokçu Kız” hikâyesi bir tekstil atölyesinde ölü bulunan Gülseren isimli genç kızın ölümünü aydınlatmaya çalışan Başkomiser Nevzat ve ekibinin soruşturmasını anlatır. Gülseren'i "namus meselesi" yüzünden erkek kardeşi Gülabi mi öldürmüştür? Yoksa artık aşkına cevap vermediği için eski erkek arkadaşı Kirpi Çetesi’nin lideri Zeko mu öldürmüştür? Ya da Gülseren'in herkesten sır gibi sakladığı sevgilisi Hasan mı öldürmüştür? Bu üç ihtimal üzerinden soruşturmayı yürüten cinayet büro ekibi ilgili şahısları sorgularken okur da eşitsiz toplumsal cinsiyet ilişkilerinin sürekli ve yeniden inşa sürecini izleme firsatı bulur. Tekstil atölyesinde "cansız bedeni, dikiş makinasının yanına" (Ümit 2019, 99) düşüp kalmış Gülseren erkek egemen toplumun kadın üzerindeki sistematik eril tahakkümünü örnekleyen bir imgedir hikâyede. Gülseren'in cansız bedeni sesi yitik kadınları ya da suskunluğa mahkûm edilmiş kadınları temsil eder; hikâyede adı vardır sesi yoktur Gülseren'in ve dahası Gülseren'i anlatanlar genellikle erkeklerdir. Gülseren'e dair pek çok şeyi genel olarak onu çepeçevre kuşatan erkeklerden ya da erkek egemenliğine suç ortaklığı eden ninesi Satı Kadın'dan öğreniriz. Gülseren'i sessizliğe mahkûm eden cinayetin katil zanlıları ise-erkek kardeş, eski erkek arkadaş ve gizli sevgili-erkek egemen toplumun cisimleşmiş halleridir ve onların da özellikle Gülseren'le olan ilişkileri temsil ettikleri erkeklikleri irdelemek açısından önemlidir. Bu yazının amacı "Overlokçu Kız" hikâyesinde toplumsal

“Öğr. Göv. Dr., Özyeğin Üniversitesi, Yabancı Diller Yüksekokulu, https://orcid.org/0000-0002-3142-9198, saniye.canci@ozyegin.edu.tr, Yazı Gönderim Tarihi: 09.09.2020, Yazı Kabul Tarihi: 05.03.2021 
cinsiyet ilişkilerinin inşa ve işleyişini hikâyenin karakterlerine odaklanarak tartışmak, temsil edilen farklı erkeklikleri incelemek ve nihayetinde eşitsiz toplumsal cinsiyet ilişkilerinin, tıpkı gerçek dünyada olduğu gibi, bu hikâyenin evrenindeki toplumun da her katmanına nüfuz ettiğini vurgulamaktır.

Erkeklik çalışmalarının öncü isimlerinden Connell ve Messerschmidt, toplumsal cinsiyet ilişkilerinin her zaman bir gerginlik alanı olduğunu belirtip bu gerginlik alanının hem kadınlar ve erkeklere hem de erkeklerin kendi arasındaki ilişkilere dair olduğunu belirtirler (Connell ve Messerschmidt 2005, 853). Farklı erkeklikler $^{1}$ arasında hiyerarşik ilişkiler olduğunun altını çizen ve hegemonik erkeklik kavramını geliştiren Connell, hegemonik erkeklik "daima kadınlarla ilgili olduğu kadar, ikincil konuma itilmiş çeşitli erkeklik biçimleriyle ilgili olarak da inşa edilmektedir" (Connell 2016, 268) diye not düşer. Dolayısıyla toplumsal cinsiyet ilişkileri tartışılırken erkeklerin hem kadınlarla hem de diğer erkeklerle olan ilişkileri mercek altına alınır. Connell, hegemonya teriminin Gramsci'den ödünç alındığına atıfta bulunarak hegemonik erkeklik tanımında hegemonyanın "kültürel süreçler" ve "toplumsal güçler oyununda" elde edilen bir "toplumsal üstünlük" (Connell 2016, 269) olduğunu belirtir. Hegemonik erkeklik belli bir grup erkeğin kendilerine egemenlik sağlayan sosyal ilişkileri nasıl oluşturup meşrulaştırdıkları ile ilgilidir (Carrigan, Connell ve Lee 1985, 592). Ancak bu silah zoruyla kazanılan bir egemenlik değildir: "Dinsel öğreti veya pratiğe, kitle iletişim içeriğine, ücret yapılarına, ev tasarımına, yardım/vergilendirme politikalarına vb. kök salan üstünlük”tür (Connell 2016, 269). Bunun yanı sıra Connell, hegemonik erkeklik ile ataerki ilişkisinin altını çizer ve şöyle der: "Hegemonik erkeklik, ataerkinin meşruluğu sorununa hâlihazırda verilmiş, kabul gören yanıtı somutlaştıran toplumsal cinsiyet pratiği tertibatıdır" (Connell 2016, 150). Dolayısıyla da hegemonik erkeklik "erkeklerin baskın, kadınlarınsa madun konumda kalmalarını teminat altına alır (veya alması beklenir)" (Connell 2019, 150-151). Hegemonik erkekliğin meşruiyet kazanmasını sağlayan toplumsal süreçler kadınların erkeklere tabi kılınmaya boyun eğmeleri ve "erkeklerin çıkar ve arzularına hizmet etmeye" yönelik pratikleri ile tanımlanan "ön plana çıkarılmış kadınlık" 2 ile de ilişkilendirilir (Connell 2016, 268). Yapılan araştırmalar kadınların erkekliklerin oluşma süreçlerinin pek çoğunda merkezi bir yer işgal ettiğini göstermektedir ve dahası toplumsal cinsiyet hiyerarşileri "kadınların, özellikle genç kadınların kimlik ve pratiklerinin yeni konfügürasyonlarının da etkisi altında bulun[maktadır]" (Messerschmidt 2019, 96). Dolayısıyla Messerschmidt erkekliklerin daha iyi anlaşılması ve incelenebilmesi için araştırmaların "kadınların pratiklerini ve kadınlıklarla erkekliklerin tarihsel karşılıklı etkileşimini daha fazla dikkate alması gerektiğini” (Messerschmidt 2019, 96) not eder. Sonuç olarak erkekliklerin hem kadınlar ve kadınlıklar hem de diğer erkekler ve erkekliklerle olan etkileşiminin incelenmesi erkekliklerin, kadınlıkların ve ataerkinin bir sistem olarak yeniden inşa sürecinin anlaşılması bağlamında önemlidir.

\section{Toplumsal Cinsiyet İlişkileri ve Erkeklik Temsilleri}

Gülseren'in etrafındaki erkekler toplumsal cinsiyet ilişkileri ve işleyişine dair pek çok ipucu verirler. Bu noktada ilk olarak Gülseren'in eski sevgilisi ve Kirpi Çetesi'nin lideri Zeko'nun sosyal çevresine odaklanıp sonra da Zeko'nun erkeklik pratikleri tartışılacaktır. Zeko erkekliğini öncelikle şiddet eylemi üzerinden kurgular. Kirpi Çetesi; Bağcılar'da yaşayan Zeko, Gülseren'in kardeşi Gülabi, Duran ve Bayram'dan oluşan bir mahalle çetesidir. Zeko'nun liderliğinde çete üyelerinin mahallede kabadayılık yaptıkları, bazı dükkânları soyup çaldıkları malzemeleri sattıkları, uyuşturucu işine bulaşıp yaralama olaylarına karıştıkları bilinir. Böyle zorbalıklarla mahalleliyi sindiren bu gençler Zeko'dan çekinirlerken mahallede kendilerini "kral” (Ümit 2019, 103) gibi görmeye başlarlar. Alt sınıf bir aileden gelen Zeko'nun ailevi sorunları da vardır. Zeko'nun babası "genelevlere dadanmış" (Ümit 2019, 119), AIDS kapmış ve eşine AIDS bulaştırmıştır. Zeko'nun annesi hastanede tedavi görmektedir ve Zeko çete üyelerinin annesinin AIDS’ten dolayı tedavi altında olduğunu öğrenmesinden çekinir çünkü annesinin namusuna laf edilmesinden ve rezil olmaktan korkmaktadır. Hatta bu durumdan öylesine çekinmektedir ki cinayetin işlendiği saatlerde hastanede annesinin yanında olduğunu bile saklamaya çalışır önce. Gülseren'le ilgili bildiklerini cinayet büro ekibi annesinin hastalığını sır olarak saklarsa anlatacağııı söyler. Gülseren'le olan ilişkisinden dolayı çete üyeleri Zeko’ya düşman kesilince ve annesinin durumunun öğrenilmesi ihtimali de eklenince Zeko çete üyelerine karşı kendini zayıf ve savunmasız hissetmektedir. $\mathrm{Bu}$ durumda çete içinde kaybetmiş olduğu hâkim pozisyonu şiddete başvurarak yeniden inşa etmeye çalışır. Dolayısıyla Zeko çete içinde işler yolunda giderken çete üyeleriyle birlikte etrafa şiddet uygularken ve çete üyeleriyle arası bozulduğunda da çete üyelerine karşı şiddet uygularken erkekliğini kurgulamaktadır. Bu durum Connell'ın bazı erkeklerin üstünlüklerini kanıtlayabilmek için fiziksel saldırganlık gösterdikleri savıyla açıklanabilir (Connell 2016, 135). Zeko'nun erkeklik pratiklerine yakından bakabilmek adına Zeko ve çete üyeleri arasındaki ilişkileri gözden geçirmek yerinde olacaktır. 
Çetenin üyeleri Duran, Bayram ve Gülabi, Zeko Gülabi’nin ablası Gülseren'e âşık oluncaya dek onu liderleri olarak görürler. Zeko'nun Gülseren'in peşine düşmesi Zeko'nun çete içindeki konumunu sarsar. Çete üyeleri böyle bir davranışı erkeklik etik kodlarına yakıştıramaz. Duran, Zeko ile aralarındaki ilişkinin neden ters yüz olduğunu şöyle anlatır: "Eskiden arkadaştık, daha doğrusu abi diyorduk ona. Ama kalıbının adamı değilmiş, hepimizi sattı. Üstelik namus haini çıktı. ... Gülseren Abla’ya âşıktı bu puşt” (Ümit 2019, 112). Duran'ın Zeko’yu "namus haini” olarak nitelendirmesi Bourdieu'nün sembolik sermaye olarak şeref kavramı tartışmasını çağrıştırmaktadır. Bourdieu’ye göre, kadınlar erkekler için şeref gibi toplumsal statü sağlayan sembolik sermayenin üretilmesindeki en önemli araçlardan biridir ve kadının sembolik değeri erkeğin toplum içinde elde edeceği sembolik kâr demektir: Başka bir deyişle, erkeğin elde edeceği sembolik kâr, kadının "şerefine ve bilhassa da ... iffetine bağlıdır” (Bourdieu 2015, 63). Bu bağlamda Gülseren'in iffeti Gülabi ve Gülabi'nin yakın arkadaşları Duran ve Bayram için dokunulmaz bir değerdir. Eğer Gülseren iffetini kaybederse ya da hikâyede olduğu gibi Zeko tarafından ayartılmaya çalışılırsa bu müdahale edilmesi gereken bir durum yaratır. Sembolik sermayeye el uzatan çetenin lideri de olsa o kişi alt edilmeye çalışılır. Nitekim Gülabi'nin uyuşturucu etkisinde olduğu ve kendine gelmesi için gözaltında tutulduğu sırada-bu işi Gülabi yapamayacak olduğu için olsa gerek-Bayram ve Duran, Zeko’yu dövmeye kalkarlar.

Bu dört erkeğin arasındaki ilişki bir bakıma Gülseren'in bedeni üzerinden şekillenir. Bir zamanlar çete üyelerinin gözünde özenilen ve saygı duyulan erkek olan Zeko alaşağı edilir çünkü Gülabi’nin şerefine el uzatmıştır. Zeko, erkek egemen toplumda bir başka erkeğin egemenlik alanına girmiş ve Gülabi nazarında ataerkil gücün istikrarına gölge düşürmüştür. Gülabi, sembolik sermayesi olan Gülseren'in iffetini koruyabildiği oranda erkek egemen söylemin meşruluğuna yanıt verebilecektir. Dolayısıyla Gülseren'e el uzatan erkeğin cezalandırılması erkek egemen toplumun erkekliğe dair beklentilerini karşılamak için sergilenen bir çaba olarak okunabilir. Duran ve Bayram'ın Gülabi ya da Gülseren ile hiçbir kan bağı olmadığı halde Gülabi'nin yokluğunda Gülabi’nin intikamının peşine düşmesi bu erkekler için kadının sembolik sermaye olarak ne derece içselleştirilmiş bir meta olduğunu gösterir. Kadın bedeni ve namusu erkek egemen toplumun yeniden üretim araç ve stratejilerine dönüşmüştür. Bourdieu'nün de dediği gibi, "yeniden üretim stratejileri sistemin temel ilkesidir ve sembolik sermayenin üretim ve yeniden üretim araçlarının tekelini ellerinde tutan erkekler, bu sermayenin korunması veya çoğaltılmasını sağlamayı hedefler” (Bourdieu 2015, 66). Dolayısıyla, Gülabi hastanede kendine gelmesi için gözaltında tutulurken Duran ve Bayram'ın Gülabi'nin şerefini korumak ve Zeko'yu da “şerefsiz” ve "kalıbının adamı olmadığı" için dövmek istemeleri, Gülseren'in iffeti üzerinden erkek egemen sistemi yeniden üretmektir denebilir.

Kirpi Çetesi'nin lideri Zeko, bulunduğu konum ve eylemleri göz önüne alındığında Messerschmidt'in “toksik, abartıl1-erkeklik" (Messerschmidt 2019, 128) olarak nitelendirdiği bir erkekliği temsil eder. Zeko "tehlikeli”, çete üyelerini "baştan çıkartan", “deli cesareti” olan ve kimseden korkmayan bir kabadayıdır (Ümit 2019, 103). Gülabi, Bayram ve Duran ise "ezik çocuklar”dır ve Zeko bu gençleri yanına alıp "Bıçak nasıl kullanılır, nasıl dövüşülür, insanlar nasıl korkutulur hepsini öğretmiş”tir (Ümit 2019, 103). Zeko, şiddet uygulama ve zorbalık gibi çoğu kez eril güce atfedilen (Bourdieu 2015, 69) eylemleri yoluyla çete üyeleri üzerinde belli bir hâkimiyet sağlamıştır. Bu durumda Zeko aynı zamanda Messerschmidt'in tahakkümcü erkeklik olarak tanımladığı olaylar ve/ya da insanlar üzerinde "güç uygulamayı" (Messerschmidt 2019, 208) tercih eden ve bu yolla kontrolü ele almaya çalışan erkeklikle de örtüşmektedir. Zorbalık yoluyla ve güç uygulayarak çeteyi kontrol eden Zeko'ya Gülabi, Bayram ve Duran “Allah gibi tapıyorlardı” ve “Zeko'nun yanında kendilerini güçlü hissediyorlar"dı (Ümit 2019, 103). Ancak daha önce de tartışıldığı gibi Zeko'nun diğerleri üzerinde kurduğu tahakkümün ömrü “raconu bozup Gülseren'e asılana kadar”dır (Ümit 2019, 103). Tekstil atölyesinin sahibi Hasan'ın anlattığına göre Gülabi, Bayram ve Duran Zeko’yu daha önce de raconu bozduğu için dövmeye kalkmışlardır. Zeko, bu kavganın sonunda çete üyelerine sözlü saldırıya devam ederken hâlihazırda kaybettiği pozisyonunu yeniden kazanmaya çalışır. Bu noktada Zeko'nun sarf ettiği sözler toplumsal cinsiyet ilişkileri bağlamında düşünülmeye değerdir. Zeko; Gülabi, Bayram ve Duran'a "“Adam mı oldunuz lan başıma?"” deyip gençleri “domaltı[p]" (Ümit 2019, 105) tecavüz etmekle tehdit eder. Zeko; Gülabi, Bayram ve Duran'1 "adam” olarak görmediğini söyleyip erkekliklerine meydan okurken, tecavüz tehdidiyle onları madunlaştırmaktadır. Başka bir deyişle, Zeko, tecavüz eylemini anarak bu erkekler üzerinde cinsel şiddet uygulamadan bahsederken kendisine güç diğerlerine ise zayıflık ve edilgenlik atfeder. Bourdieu "pek çok toplumda, eşcinsel sahip olma bir 'kudret' göstergesi, bir tahakküm edimidir (bu şekilde uygulandığında, bazı durumlarda, diğer kişiyi 'dişilleştirmek' suretiyle onun üzerinde üstünlük kurmayı sağlar)” (Bourdieu 2015, 35) der. Zeko'nun Bayram ve Duran'ı tecavüz ile tehdit etmesi Bourdieu'nün yukarıdaki savını örnekler niteliktedir. 
Zeko, çete içinde kaybettiği statüsünü ve tahakkümünü bu şekilde yeniden kazanmaya çalışırken Connell'ın hegemonik erkeklik bağlamında tartıştığı madunlaştırılmış erkeklikler tartışmasını da örnekler. Connell, madunlaştırılmış erkekliklerden bahsederken bu grubun eşcinsel erkekleri tanımladığını ve erkekler arasındaki cinsiyet hiyerarşisinde eşcinsel erkeklerin en alta yerleştirildiğini belirtir (Connell 2019, 153). Eşcinsellik, ataerkil yapıda hegemonik erkeklikte istenmeyen özellikleri içermekte ve hegemonik erkekliğin bakış açısından "kadınsılık" olarak algılanabilmektedir (Connell 2019, 153). Ancak madun erkeklik sınıfında sadece eşcinsel erkekler yoktur; "pısırık", "muhallebi çocuğu”, "ödlek” gibi hakaret içeren ifadelerin de anlattığ 1 gibi "bazı heteroseksüel erkekler ve oğlanlar da meşruiyet alanından dışlanmaktadır” (Connell 2019, 153). Burada Connell erkekliğin kadınsılıkla "bulanıklaştırıldığı”na (Connell 2019, 153) dikkat çeker. Gücünü ataerkinden almış hegemonik erkeklik kadınları madunlaştırdığı gibi eşcinsel ve bazı heteroseksüel erkekleri de madunlaştırmaktadır. Bu noktada Zeko'nun durumu ilginçtir. Zeko hegemonik erkekliği temsil etmese de, diğer bir deyişle genel olarak toplumda kabul gören bir erkekliği temsil etmese de, hegemonik erkekliğin düşünce sistemi içinde hareket edip çete üyelerini dişileştirerek madunlaştırmaya çalışmaktadır. Dolayısıyla Zeko, toplumsal cinsiyet eşitsizliğinden güç alan bir zihniyetle erkeklerden oluşmuş bu çete içindeki hiyerarşiyi yeniden kendi lehine oluşturmaya çalışmaktadır. Bununla birlikte Zeko'nun tecavüz tehdidi ve söylemi erkeklikler arasındaki hiyerarşik ilişkilerin kadın bedeni üzerinden inşa edilmesini de örnekler niteliktedir.

Zeko'nun şiddete eğilimi alt sınıf mensubu erkeklerin durumuyla ilgili bazı tespitlerle de paralellik gösterir. Sancar şöyle der:

Alt sınıf mensubu erkeklerin yani "ailenin reisleri ve piyasanın işçileri”nin aile içinde tahakkümcü, dışarıda maço erkekler oldukları genel kabul gören bir saptamadır. Bu erkeklerin para kazanarak saygın bir statü elde edememe, dolayısıyla 'egemen erkeklik' standartlarını gerçekleştirememe durumlarında yaşadıkları öfke ve eksiklik duygusunu telafi etme saikiyle böyle davrandıkları iddia edilir. (Sancar 2011, 99)

Zeko, Başkomiser Nevzat'la konuşurken kendinin alt sınıf mensubu olduğunu ifade eder bir bakıma: "Evet, pek muteber bir adam sayılmam, size göre itin önde gideneyim" (Ümit 2019, 118). Zeko, toplumsal statü eksikliğinin farkındadır ve Nevzat gibi toplumda statü sahibi diğer erkeklerin kendi gibi alt sinıf mensubu erkekleri nasıl gördüklerini böyle dile getirir. Yapılan araştırmalar alt sınıf mensubu erkeklerin şiddete yönelmelerini "tehdit altındaki erkek kimliklerini bir tür sağaltma ya da yeniden güçlendirme arzusunun" (Sancar 2011, 108) tetiklediğine işaret ediyor. Zeko'nun Gülseren'in patronu Hasan ile olan ilişkisi de böylesi bir tespiti örnekler niteliktedir. Zeko, Gülseren'i görmeye tekstil atölyesine gidince, Hasan'la kavga eder. Zeko olay1 şöyle anlatır:

O Hasan denen sümsük herif de ayrı bir yavşak. Güzellikle anlattım adama, sevgilimle aramı düzeltmek istiyorum, bana bulaşma dedim, anlamadı. Kendini patron zannediyor dümbük, erkekliği tuttu. Çaresiz ben de okşadım biraz. (Ümit 2019, 120)

Hasan ve Zeko'nun durumu ilginç ve çetrefildir. Hasan tekstil atölyesinin sahibi ve patronu olarak Zeko'nun sahip olamadığı toplumsal statüye sahiptir. Bu durumda Hasan'la karşı karşıya gelen Zeko'nun erkekliğini daha da fazla tehdit altında hissetmesi bir olasılık olarak mevcuttur. Zeko'nun kullandığı hakaret içeren dil bu olasılığın bir yansıması olarak okunabilir. Zeko, Hasan’1 “sümsük” diyerek küçültmekte ve önemsizleştirmektedir. Türk Dil Kurumu Sözlükleri "sümsük” kelimesinin "Uyuşuk davranan, miskin, aptal, mıymıntı, sünepe, pısırık” kimseler için kullanıldığını yazar (Türk Dil Kurumu Sözlükleri 2019). Zeko, Hasan'ın erkekliğine meydan okuyan bir dil kullanmakta ve onu erkeklik niteliklerinden yoksun bir kimlik olarak görme eğilimindedir. Bunu da "erkekliği tuttu" diyerek pekiştirmektedir. Benzer bir şekilde, Hasan'a "dümbük" diye hakaret ederek Hasan'ın toplum nazarında patron ve tekstil atölyesi sahibi olarak edindiği itibarı da indirgemeye çalışmaktadır. Bununla birlikte fiziksel şiddet de uygulayarak erkekliğine karşı hissettiği tehdidi savuşturma eğilimindedir. Zeko, Hasan'a uyguladığı şiddeti “biraz okşadım” diyerek örtmece yollu bir ifadeyle dile getirir. “Okşamak” kelimesinin gerçek anlamı düşünüldüğünde bu, Hasan'1 okşanan olarak edilginleştiren ve erkekliğini indirgeyen bir ifade olarak okunabilir. Böylece Zeko, hem fiziksel olarak (Hasan’1 döverken) hem de söylem düzeyinde (uyguladığı şiddet eylemini anlatırken) Hasan’ı da diğer çete üyeleri gibi madunlaştırmaya çalışmaktadır. 
Gülseren'in etrafında şekillenen diğer ilişkiler göz önüne alındığında Gülseren'in erkek kardeşi Gülabi ve Gülseren'in ninesi Satı Kadın arasındaki diyaloglara odaklanmak erkek egemen sistemin ve eşit olmayan toplumsal cinsiyet ilişkilerinin kadınlar yoluyla da yeniden üretilebileceğini tartışmak açısından önemlidir. Gülabi, katil zanlısı olarak sorgulanan karakterlerden biridir ve hikâyede pek az görünür. Bağcılar'da yaşayan, henüz reşit bile olmayan Gülabi, uyuşturucu yüzünden hastanede yatmış, torbacılık yapmış, tekstil atölyesinin sahibi Hasan'ın tabiriyle “Apaçi denen gençlerdendir” (Ümit 2019, 102). Ablası Gülseren, Gülabi'ye kol kanat germiş, çalıştığı tekstil atölyesine Gülabi'yi gece bekçisi olarak aldırmıştır. Gülabi’nin ve Gülseren'in anneleri ölmüştür, babaları Vehbi ise annesi Satı Kadın'ın “oyuncağı olmuş” (Ümit 2019, 114) pasif bir adamdır. Gülabi’nin yaşadığı evde ne Gülabi'nin ne ablası Gülseren'in ne de babaları Vehbi'nin sözü geçer. Bu evde tek söz sahibi ve iktidarı temsil eden Satı Kadın'dır. Gülabi ise erkekliğini aşağıda örnekleriyle tartışılacağı gibi Satı Kadın'ın ataerkil sistemi yeniden üreten ve erkeğin kadından üstünlüğünü vurgulayan baskıcı söylemlerinin egemen olduğu bir atmosferde kurgulamaktadır. Okurun Gülabi’yle karşılaştığı ilk sahnede Gülabi kendinde değildir ve Başkomiser Nevzat, Gülabi’yi şöyle anlatır: "Delikanlının garip bir hali vardı, adım atmaya üşenir gibiydi, yardımcımın itelemesiyle yürüyordu. ... bön bön etrafına bakınıyor ama hiçbirimizi görmüyordu" (Ümit 2019, 100). Gülabi uyuşturucu etkisi altındadır ve burada Ali'nin “itelemesiyle" yürüyen Gülabi imgesi, Gülabi’nin kendi iradesini kullanmaktan uzak bir karakter olmasını simgeler. Gülabi’nin altında ezildiği güç ise "cadı" olarak nitelediği ninesidir. Kendine gelinceye kadar hastanede tutulan Gülabi, hikâyede ikinci ve son kez görüldüğü sorgulama sahnesinde cinayeti kendisinin işlemiş olabileceğini düşünüp "Allah belamı versin benim. Demek uydum o cadının sözlerine" (Ümit 2019, 131) dedikten sonra neden bunu yapmış olabileceğini şöyle açıklar:

Gece gündüz beynimi yiyordu. 'Ablan orospu oldu' diyordu. 'Gördüğü her erkeğin altına yatıyor' diyordu. En son dün sabah kahvaltı ederken Gülseren Ablam’ın midesi bulandı. Kendini tuvalete zor attı. Ninem kulağıma eğildi, 'Görüyor musun, ablan hamile kalmış. Bizi rezil edecek bu kız. Bir erkek olup cezasını veremedin şunun’ dedi. (Ümit 2019, 132)

Satı Kadın’a göre Gülabi, Gülseren'i cezalandırdığında “erkek” olabilecektir. Daha önce de tartışıldığı gibi Gülseren'in iffeti Gülabi’nin sembolik sermayesini temsil ettiği için Gülseren'in iffetine sahip çıktığında Gülabi erkekliğini gösterebilecek ve bu hikâyede erkek egemen toplumun temsilcisi olan Satı Kadın'ın gözünde erkekliği teyit edilecektir. hooks'un tanımına göre, ataerki erkekleri “zayıf olarak algılanan herşeyden ve herkesten, özellikle kadınlardan üstün” kabul eder ve erkeklerin zayıf olanın üstündeki hâkimiyetlerinin devamını "şiddet yoluyla sürdürme hakkının" olduğunu iddia eder (hooks 2018, 33). Bu tanım çerçevesinde Satı Kadın tam da bu şiddet eylemine denk düşecek bir söylem ile Gülabi’yi kışkırtmaktadır. Satı Kadın'ın sözleri, hooks'un kadınların da erkekler kadar ataerkil sisteme sahip çıkabilir savını da doğrular niteliktedir (hooks 2018, 28). Satı Kadın'ın Gülseren'in çalışmasını istememesi, giyimine kuşamına karışması ve Gülabi'yi “Sen de erkek misin?" (Ümit 2019, 113) diyerek Gülseren'e müdahale etmediği için eleştirmesi hooks’un belirttiği gibi kadınların da ataerkil sisteme "dahil olmak üzere" sosyalleştirildiklerini göstermektedir (hooks 2018, 38). Satı Kadın Gülabi’nin katil zanlısı olarak alıkonulduğunu öğrendiğinde bununla neredeyse gurur duyar. Ona göre, eğer Gülabi Gülseren'i öldürdüyse "ablasının yaptığı ahlaksızlıkları görmüştür ve de kendine yakışanı yapmıştır” (Ümit 2019, 124). Satı Kadın'a göre erkek şiddeti meşrudur ve sistemin devamı için gereklidir çünkü Gülseren onu yani temsil ettiği erkek egemen sistemi "Dinlememiştir. Onca yıllık ninesini saymamıştır" (Ümit 2019, 124). Sonuç olarak Satı Kadın Gülseren nazarında erkek egemen sisteme direnen kadınlara, Gülabi nazarında da sisteme ayak uydur(a)mayan erkeklere müdahale eden ve erkek egemen sistemin yeniden üretilmesini sağlayan bir araçtır. Bu noktada Satı Kadın, Connell’ın ön plana çıkarılmış kadınlık olarak adlandırdığı erkeklere tabi olmayı onaylayan kadınlığı simgeler (Connell 2016, 268) ki bu da erkek egemen toplumda hegemonik erkeklikle suç ortaklığı olarak değerlendirilebilir. Dolayısıyla Satı Kadın da eşit olmayan toplumsal cinsiyet ilişkilerinin inşa sürecinde rol oynar.

Gülseren'in patronu, herkesten sakladığı sevgilisi ve katili olan Hasan ise kadına uygulanan şiddetin sorumlusunun bizzat kadının kendisi olduğunu düşünen eril zihniyeti temsil etmektedir. Hasan hikâyenin bir başında bir de sonunda görülür ve hakkında bildiklerimiz epey sınırlıdır. Evlidir ve iki çocuk sahibidir, Gülseren'le bir ilişkisi vardır ve Gülseren hamile kalmıştır. Hasan'a göre onu baştan çıkaran Gülseren'dir. Hasan "Allem etti kallem etti, aklımı başımdan aldı, beni yoldan çıkardı. ... Beni kandırdı, beni kullandı, çünkü gözü paramdaydı" (Ümit 2019, 149-150) diyerek Gülseren'i bu ilişkinin tek sorumlusu ilan eder. Türkiye'de Kadına 
Yönelik Aile İçi Şiddet Araştırması'na göre, araştırma için mülakat yapılan erkekler genel olarak yaraladıkları ya da öldürdükleri kadınları suçlamaya çalışmışlardır (Yüksel-Kaptanoğlu 2015, 243). Adı geçen araştırmanın bulgularıyla paralel olarak bu kurmaca dünyanın karakterlerinden biri olan Hasan da aynı eğilimdedir. Gülseren'i öldürüp hem Gülseren hem de gayrimeşru çocuğundan kurtulmak isteyen Hasan, Gülseren’i kötüleyerek işlediği cinayeti gerekçelendirmeye de çalışır. Kara ve Uluç’un dediği gibi, toplumda "itaat, uyum ve iffet rejimini askıya alan-ihlal eden her kadınlık biçimi (ve kadın) saygınlık, meşruiyet ve değerden yoksun bırakılır" (Kara ve Uluç 2019, 1576). Kara ve Uluç saygınlıktan mahrum bırakma ve şiddet eylemi arasında anlamlı bir ilişki olduğunu ifade edip “[ş]iddet olgusu, kadının icra ve inşa ettiği 'kadınlığının’ saygınlıktan mahrum bırakılmasıyla deneyimlenir" (Kara ve Uluç 2019, 1575) tespitini yaparlar. Gülseren'in katili Hasan, bu tespiti doğrular nitelikte bir örnektir. Hasan, bir yandan "Ben Gülseren'i öz kızım gibi görüyordum” (Ümit 2019, 149) diyerek kendini aklamaya çalışırken diğer yandan Gülseren "çok kurnazdı," "bilhassa hamile kaldı", “"Benimle evleneceksin’ dedi," “Gözü yükseklerdeydi” (Ümit 2019, 149) gibi ifadelerle Gülseren’in saygınlık ve iffetten uzak olduğunu ima eder ve işlediği cinayeti meşru kılmaya çalışır. Başkomiser Nevzat'a "Çaresiz kaldım. İnanın bana çaresiz kaldım” (Ümit 2019, 149) diyerek öldürmeyi bir çözümmüş gibi sunar. Her ne kadar işlediği cinayetten pişmanlık duyduğunu söylese de Hasan'ın sözleri kadını ötekileştiren, ikincilleştiren ve kadına şiddeti "müstahak" gören eril zihniyetin hikâyede vücut bulmuş halidir.

“Overlokçu Kız”da hegemonik erkeklik örüntülerinden oluşmuş ataerkil sistemin madunlaştırdığ1 eşcinsel erkekleri temsil eden karakter ise Satı Kadın'ın Gülseren'i evlendirmek istediği Serhat’tır. Yirmi yaşlarındaki Serhat, Esenler'de tüm sülalesiyle birlikte bir aile apartmanında yaşamakta ve aynı zamanda da apartmanın altındaki manav dükkânını işletmektedir. Eşcinsel olduğunu ailesi ve mahalleliden gizlemeyen Serhat, bu durumun sıkıntısını da hissetmektedir. Serhat'ın ailesi zorla da olsa Serhat'ı kabul etmiştir ama Serhat mahallelinin onu dışladığının farkındadır. Öte yandan Gülseren ve Serhat'ın aileleri arasında kan davası vardır ve Satı Kadın, Gülseren'i Serhat'a verirse kan davasını bitireceğine inanır. Bunu öğrenen cinayet büro ekibi Serhat'ı da sorgulamak üzere Serhat'ın manav dükkânına gider. Arkadaşları tarafından "Serhoş" diye hitap edilen Serhat'1 Başkomiser Nevzat şöyle tarif eder:

Sesi bir çocuğunki gibi inceydi. Yoksa bir kadınınki gibi mi demeliyim? . . Narin bedenini bize çevirdi, ölçülü adımlarla yaklaştı. . . . Uzun kirpiklerinin arkasındaki gözleri siyah birer elmas gibi ışıldıyordu, biraz çarpık burnunu saymazsak, kalın dudakları yüzüne bir genç kız havası veriyordu. (Ümit 2019, 126-127).

Serhat ya da Serhoş hikâyede eşcinsel erkeklerin dışlanmışlığının sembolüdür. Connell'ın dediği gibi ataerkil düşünce sisteminde "eşcinsellik, hegemonik erkeklikten simgesel olarak dışlanan ne varsa onu bünyesinde barındırır" (Connell 2019, 153). Serhat'ın ince sesi, narin bedeni, uzun kirpikleri, kalın dudaklarıyla somutlaştırılan imgesi hegemonik erkeklikte istenmeyen "kadınsı" özelliklerdir. Schippers'a göre hegemonik erkeklik kültürel olarak desteklenen özelliklerle meşruluk kazanır (Schippers 2007, 96). Dişi olan ve dişilik ile özdeşleştirilen özellikler "aşağı derecede" ve "arzu edilmeyen" toplumsal cinsiyet özellikleri olarak tanımlanırken erkeklik ise "üstün” olarak kalmalı ve hiçbir surette "arzu edilmeyen” özelliklerle ilişkilendirilmemelidir (Schippers 2007, 96). Bu erkek egemenliğinin "kültürel sigortası” olarak kabul edilir ve kendi cinsiyet kategorisine özgü hegemonik özelliklerle bağdaşmayan bir erkek kadınsı ve sorunlu olarak damgalanır (Schippers 2007, 96). Dolayısıyla Serhoş olarak anılıp kadınlara özgü olduğu düşünülen sıfatlarla temsil edilen Serhat, erkek egemen toplumun reddettiği bir karakterdir. Serhat "çok sopa yedim, çok iş geldi başıma ama kabul ettiler sonunda" (Ümit 2019, 129) diyerek ailesi tarafindan inkâr edilişini ama aynı zamanda da zoraki olarak kabul edilişini ifade eder. Ailesi zoraki olarak Serhat'1 kabul etse de Serhat toplumun "öteki" olarak dışladığıdır. Başkomiser Nevzat'a pis ve kanunsuz bir işe bulaşmadığını anlatmaya çalışırken caddedeki diğer dükkânlara bakar ve şöyle der Serhat: "Onlar gibi değilim diye iftira ediyorlar” (Ümit 2019, 128). "Onlar gibi” olmayan ve toplumun beklediği tipik eril davranışları sergilemeyen Serhat'ın durumu eşitsiz toplumsal cinsiyet ilişkilerinin göstergesidir.

Messerschmidt eşitsiz toplumsal cinsiyet ilişkilerinin inşa sürecinde ilişkisellik kavramını vurgular:

Hegemonik erkekliğin, vurgulanan kadınlık-ve hegemonik olmayan erkeklikler-ya da hegemonik erkekliği tamamlayan, ona itaat eden ve ona tâbi bulunan kadınlık biçimleriyle kurduğu ilişki dışında 
anlamı yoktur. Bu bağlılık ve üstünlük ilişkisinin meşrulaştırılması, hegemonik erkekliğin anlamını ve özünü ortaya çıkarır. (Messerschmidt 2019, 60)

Bu noktada komiser yardımcısı Ali’nin Serhat ile karşılaşması Ali’nin erkekliğine dair ipuçları verir niteliktedir. Hikâye boyunca Ali hakkında öğrenebildiklerimiz onun diğer karakterlerle olan iletişim ve etkileşimlerinden yola çıkarak elde edebileceğimiz durumlarla sınırlı olmasına rağmen Ali'nin cinsiyetçi ve şiddete meyilli bir erkek olduğunu söylemek yanlış olmaz. Ali'nin diğer erkeklerle olan diyalog ve ilişkileri bu çıkarımı doğrular niteliktedir. Ali, Serhat'ı ilk gördüğünde "alaycı bir sesle" "Kızı bununla mı evlendireceklermiş? ... Eşcinsel bu ya!" (Ümit 2019, 127) der. Ali'nin Serhat'1 işaret etmek için küçümseme ve horlama ifade eden "bu” zamirini kullanması Ali’nin toplumsal cinsiyet eşitsizliğini meşrulaştıran eşitsiz ilişkileri inşa etme girişimini gösterir. Bu çerçevede Ali'nin söylem düzeyindeki bu pratiği heteroseksüel erkeklerle eşcinsel erkekler arasında olduğu varsayılan hiyerarşinin yeniden üretilme pratiğidir ve dolayısıyla Ali hegemonik erkeklik örüntüsü içinde hareket etmektedir denebilir.

Messerschmidt "meşru kılıcı etkilerine ek olarak" hegemonik erkekliğin her zaman olmamakla birlikte tahakkümcü olabileceğini not eder (Messerschmidt 2019, 208). Buna paralel olarak hegemonik erkeklik örüntüleri içinde hareket eden Ali’yi diğer erkeklerle olan ilişkilerinde tahakkümcü bir erkeklik inşa ederken de görmek mümkündür. Hikâye boyunca "sert" erkeği temsil eden Ali genel olarak şiddete meyilli, tehlike durumlarında gözünü karartıp risk alan ve zorbalıktan kaçınmayan biridir. Hikâyenin ilk sahnesinde "tehditkâr sesi” (Ümit 2019, 99) atölyede yankılanan, Kirpi Çetesi üyelerinin kavgasını görünce kavganın ortasına dalan, kendine bıçak çekildiğinde "sakin bir tavırla ve adeta bir dansçı çevikliğiyle" (Ümit 2019, 109) tehlikeyi savuşturup rakibini etkisiz hale getirdikten sonra "suratına okkalı bir de kafa" (Ümit 2019, 109) atan Ali tahakkümcü eril davranışlar sergiler. Ali’nin suratına kafa attığı kişi Zeko’dur ve olay sonrasında Zeko, Ali’ye "gıptayla" (Ümit 2019, 119) bakar ve "Sizde de ne kafa varmış amirim, az kalsın burnum beynime yapışacaktı" (Ümit 2019, 119) der. Zeko'nun Ali’yi öven bu tavrı erkeklikler arasındaki hiyerarşiyi gösterir. Ali'nin tahakkümcü erkekliğinin başka bir bağlamda toksik ve tahakkümcü erkeklikler sergileyen Zeko tarafından övülmesi eşitsiz toplumsal cinsiyet ilişkilerini meşrulaştıracak bir tavır olarak okunabilir.

Ali eşitsiz toplumsal cinsiyet ilişkilerini sorgulamaktan uzak bir karakterdir. Serhat'ın sorgusu esnasında Serhat cinayet büro ekibine aslında kendi ailesinin kan davasının peşini çoktan bıraktığını ve Gülseren'le de evlenmelerine gerek kalmadığını söyler. Sorgu sonrası Başkomiser Nevzat'la durum değerlendirmesi yapmaya çalışan Ali şöyle der: "Nasıl yani, zavallı kız boş yere mi öldü şimdi? ... Ortalıkta bir sebep bile yokmuş" (Ümit 2019, 130). Ali'nin söylemi sorunludur. Başkomiser Nevzat'1n da dediği gibi "Gerçekten de Serhat'la evlenecek olsaydı, kız boşa ölmemiş mi olacaktı” (Ümit 2019, 130). Ali, Gülseren'in öldürülmesini sorgulamak yerine Gülseren'in ölümünün boşuna olmadığını gösterecek bir sebep arayışında gibidir. Kadının öldürülmesinin kabul edilemez bir şey olmasını düşünmek yerine kadının öldürülmesinin geçerli bir gerekçesi olup olmadığının peşine düşen Ali, eril hâkimiyetin olduğu toplumda kadın hayatının değerini sorgulatmak adına üstüne düşünülmesi gereken bir karakterdir.

“Overlokçu Kız”ın başkarakteri Başkomiser Nevzat genellikle olumlu erkekliklerin temsilidir. Nevzat Balat'ta yaşayan bekâr bir erkektir. Tatavla adlı meyhaneyi işleten sevgilisi Evgenia ile uzun zamandan beri devam eden bir ilişkisi vardır. Evgenia Suriye göçmeni olan Azez’i evlat edindikten sonra Nevzat da Azez'e babalık yapmaya başlar. Nevzat cinsiyetçilik ve ayrımcılıktan hoşlanmayan ve yardımcısı Ali'yi cinsiyetçi tutumlarından dolayı eleştiren bir erkektir. Messerschmidt'in tanımına göre olumlu erkeklikler "erkeklerle kadınlar erkeklikle kadınlık ve erkeklikler arasında eşitlikçi ilişkileri meşru kılmaya katkı sunan (yerel, bölgesel ve küresel) toplumsal cinsiyet inşalarıdır" ve bu tip erkeklikler hegemonik ilişkilerin gerçek alternatifi olduğu için "karşıhegemoniktir" (Messerschmidt 2019, 234). Başkomiser Nevzat bu kıstaslara uyacak nitelikte tavırlar sergiler. Gülseren'in bir sevgilisi olduğu için öldürülmüş olma ihtimalini öğrenince Nevzat'ın aklından geçenler Nevzat'ın erkek egemen toplumun düşünce sistemini benimsemediğini gösterir:

Tek suçu bir sevgilisi olması mıydı? Saçmaydı ama bu ülkede öldürülen pek çok genç kız gibi bu son derece doğal ilişkisi yüzünden katledilmiş olma ihtimali yüksekti. Onu serseri olmasın diye işe aldırdığı kardeşi mi öldürmüştü gerçekten? Neden olmasın, Gülabi gibi birçok cahil erkek, namustu, şerefti, töreydi diye kız kardeşlerini hunharca katletmiyor muydu bu ülkede? (Ümit 2019, 108) 
Burada Nevzat eril toplumların kadını sembolik sermaye olarak görmesine karşı çıkarken toplumsal bir eleştiri yapar. Gülseren'in Satı Kadın’ın evlendirmek istediği kişiyle evlenmeyip bir erkek arkadaş edinmesi sembolik sermayenin "merkezi aygitı" (Bourdieu 2015, 59) olarak tanımlanan evlilik kurumunu reddetmesidir. Bourdieu'nün dediği gibi eril iktidar için evlilik aygıtında kadınlar "sembolik sermayenin devam ettirilmesi ve arttırılmasına katkı sunmak işlevini taşıyan semboller olarak var olabilir sadece" (Bourdieu 2015, 59-60). Bu bağlamda Gülseren'in ona dayatılan bir evliliği reddedip kendine bir sevgili bulması eril iktidara başkaldırmasıdır. Nevzat, Gülseren'in durumuyla empati kurup eril iktidarın yaptırımını eleştirerek olumlu erkeklik sergiler.

Nevzat'ın tipik eril şiddet pratiklerinden uzak durması da onun olumlu erkeklik sergilediğinin göstergesidir. Nevzat'ın sevgilisi Evgenia'nın evlatlığı Suriye göçmeni Azez’i uyum sorunu yaşadığı için gittiği okuldan atmak isterler. Evgenia, okul müdürünün Azez'i göçmen olduğu için atmak istediğini sezince şikâyette bulunacağını söyler. Okul müdürü ise "Bildiğiniz yere şikâyet edin, zaten bıktık bu Suriyelilerden” (Ümit 2019, 136) der. Olanları öğrenen Nevzat'ın genel tavrı olumlu erkeklikle bağdaştırılabilir. Duruma çok sinirlenen Nevzat duygularını şöyle ifade eder: "kan beynime sıçramıştı, şeytan kalk git, bul şu herifi, eşek sudan gelinceye kadar döv diyordu, elbette yapmadım" (Ümit 2019, 136). Nevzat durumu içine sindiremese de şiddete başvurmaktan kaçınır ki bu Nevzat'ın olumlu erkekliğini örnekleyen bir davranıştır.

Bunların yanı sıra hikâyede Nevzat, farklı erkeklik pratikleri de sergiler. Nevzat'ın okul müdürüyle yüz yüze olan diyaloğu Nevzat'ın o bağlam ve ortamda tahakkümcü denebilecek nitelikte bir erkeklik sergilediğini de gösterir. Nevzat okul müdürünün TC kimlik numarasını ister ve bunu da şöyle açılar:

Suç işlemeye meyilli bir şahıssınız, yani şüphelisiniz. Belki de suç işlediniz. Daha önce ne tür olaylara bulaştınız, onları öğrenmek için bu bilgiler lazım. Bakmayın öyle yüzüme, GBT’nizi kontrol edeceğim. Siz ırkçısınız. Irkçılık evrensel bir suçtur. Bu suçtan ceza alıp almadığınızı sorduracağım. Ve mümkünse size işten el çektireceğim. (Ümit 2019, 138)

Nevzat'ın mesleki otoritesini kullanarak tehditkâr bir söylem kullanması bu diyalog bazında Nevzat'ın tahakkümüne işaret eder. Öte yandan ırkçılık karşıtı söylemi ise Nevzat'ın olumlu erkekliğini gösterir. Bunun yanı sıra Nevzat geçici hegemonik erkeklik örüntüsü içinde de yer alır. Messerschmidt'e göre, geçici hegemonik erkeklikler "kısa süreyle deneyimlenirler, ömürleri kısa ve bir anlık deneyimlerdir" (Messerschmidt 2019, 158). Azez'in yeniden okula devam edebileceği haberini alan Evgenia ile Nevzat arasındaki diyalog böylesi bir geçici hegemonik erkekliğe işaret eder. Şöyle ki, Evgenia Nevzat'a teşekkür eder ve "İște bunun için seviyorum seni. Adam gibi adam olduğun için" (Ümit 2019, 139) der. Burada Evgenia'nın “adam gibi adam” ifadesinin üzerinde durmak yerinde olabilir. Türk Dil Kurumu Sözlükleri "adam” kelimesi için çeşitli açıklamalar içerir. Sözlükte yer alan sıraya göre bu açılamalar şöyledir. "İnsan”, "Erkek kişi”, "Birinin yanında bulunan ve işini yapan kimse”, "Birinin yararlandığı, kullandığı kimse", "Daima birinin yanında olan, onu destekleyen, isteklerini yerine getiren kimse", "Görevli kimse", "İyi huylu, güvenilir kimse", "Bir alanı benimseyen kimse", "Eş, koca" (Türk Dil Kurumu Sözlükleri 2019). Sözlük aynı zamanda "adam gibi” deyimini şöyle açıklar: "terbiyeli, akılllı uslu”, "adamlığa, insanlığa yarışır yolda" ve "iyice” (Türk Dil Kurumu Sözlükleri 2019). "Adam” kelimesi üzerinde durmadan önce sözlüğün "kadın" kelimesi için sıraladığı açıklamaları da not etmek faydalı olabilir. "Kadın" kelimesi için deyimler hariç dört açıklama verilmiştir. Bunlar sırasıyla şöyledir: "Erişkin dişi insan, hatun, hatun kişi, zen", "Analık veya ev yönetimi bakımından gereken erdemleri, becerileri olan", "Hizmetçi bayan" ve "Bayan” (Türk Dil Kurumu Sözlükleri 2019). "Adam” kelimesinin ilk anlamı genel olarak insana atıfta bulunsa da hem "adam" kelimesi hem de "adam gibi” ifadesi söylem bazında eril-dişil arasındaki hiyerarşik sisteme işaret eder. Bu durum sözlükte "kadın" kelimesinin açıklamalarında "erkek" kelimesinde olduğu gibi yüceltici ya da övücü referanslar olmadığı düșünülürse daha da dikkat çekici bir hal alır. Şöyle ki, "adam” kelimesinin birinin yanında olup, onu desteklemesi, isteklerini yerine getirmesi, iyi huylu ve güvenilir olması gibi olumlu anlamlarından yola çıkarak kelimeyi "kadın" kelimesi ve referanslarıyla karşılaştırdığımızda "kadın" kelimesinin bu vasıflardan yana eksik kaldığı görülür. "Kadın” kelimesinin sadece analık, ev yönetimi ve hizmetçilikle ilişkilendirilmesi "adam" ve "kadın" kelimelerinin algılanmasındaki hiyerarşiyi ima eder. Bu durumda Evgenia belki de farkında olmadan Nevzat'ın "adamlığını” överken eşitsiz toplumsal cinsiyet ilişkilerini meşrulaştıracak bir söylem kullanmaktadır. Toplumsal cinsiyet ilişkilerinde hegemonya "eşit olmayan toplumsal cinsiyet ilişkilerine rıza göstermeye, bu ilişkiler etrafında birleştirilmeye dâhil olmaya teşvik eden kültürel hüküm-söylemsel ikna-yoluyla" (Messerschmidt 2019, 60) yani "rıza ve aktif katılım yoluyla inşa 
edilir" (Messerschmidt 2019, 77) ve hegemonik erkekliğin başarısı buna bağlanır. Yukarıdaki örnekte Evgenia'nın Nevzat'ın “adamlığını” överken “adam” ve "kadın” kelimelerinin referanslarını düşünmediği kabul edilebilir. Ancak bu Evgenia'nın eşitsiz toplumsal cinsiyet ilişkilerinin inşasına ve hegemonik erkeklik örüntülerine dâhil olmadığ 1 anlamına gelmez. Nevzat'ın Evgenia'ya cevabı da yine benzer şekilde okunabilir: Nevzat "Buna itiraz etmem bak, eğer sen beni seveceksen, ben de adam gibi adam olmaya çalışırım hep" (Ümit 2019, 139) der. Bu kültürel olarak eril niteliklerin yükselişte olduğu geçici hegemonik erkeklik örüntüsünün gözlemlendiği bir an olarak değerlendirilebilir. Messerschmidt'e göre, geçici hegemonik erkeklik söylem ve pratikleri "her yere yayılmış" olabilir ancak "çok iyi gizlenmişlerdir" (Messerschmidt 2019, 158). Nevzat ve Evgenia örneği de her an her yerde ortaya çıkabilecek bir durum olabilir ancak bunun bir hegemonik erkeklik örüntüsü olarak görülmesi zor olabilir. Bunun dışında genel olarak olumlu erkekliği temsil eden Nevzat'ın bir sosyal ilişkide tahakkümcü ve bir başka bağlamda geçici hegemonik erkeklik örüntüsüne dâhil olması bir erkeğin farklı düzlemlerde farklı erkeklikler sergileyebileceğini de göstermektedir.

\section{Gülseren'e Dair Anlatılanların Anlamı}

Gülseren'in mutlak bir sessizlik içinde olduğu ve sadece cesedini gördüğümüz bu hikâyede Gülseren'i Gülseren'in etrafındaki zanlıların anlatılarından tanımaya çalışırız. Bu anlatılar genel olarak kadın düşmanı söylemler olarak karşımıza çıkar. Zeko, polis sorgusunda Gülseren'e dair bildiklerini anlatırken Gülseren'in "rahat" (Ümit 2019, 119) bir kız olduğunu söyler. Zeko, Gülseren'e "yazılmak" gibi bir niyeti olmadığını iddia edip asıl "kız bana yürüdü” (Ümit 2019, 119) der. Zeko’ya göre bu ilişkiyi başlatan ve Zeko'nun aklını çelen Gülseren'dir. Gülseren güzel olduğu kadar zeki bir kızdır; Zeko’ya göre öyle zekidir ki “şeytana pabucunu ters giydirir” (Ümit 2019, 120). Zeko’nun anlattıklarına göre Gülseren yalancıdır, “zehir” gibidir, “değme oyunculara taş çıkartır” (Ümit 2019, 121), öyle ki yeni sevgilisini Zeko dâhil herkesten saklamıştır. Dahası Zeko'ya göre "Gülseren gibi kadınlar, adamı kolaylıkla katil edebilir” çünkü Gülseren "güzel olduğu kadar vefasız, güzel olduğu kadar bencil bir kızdı[r]” (Ümit 2019, 121). Zeko gibi Hasan da Gülseren’i kadın düşmanı bir dille tarif eder. Hasan'ın Gülseren hakkında ilk sorgusunda ve son sorgusunda söyledikleri çelişkilidir. Hikâyenin başında sorgulanan Hasan Gülseren'in işi çabuk öğrenen, işini aksatmayan, “düzgün” (Ümit 2019, 104) ve Zeko gibi bir "herifle" (Ümit 2019, 104) işi olmayacak bir kız olduğunu söyler. Hasan'a göre Gülseren namuslu, sorumluluk sahibi, başı önde işine gidip gelen, lükse düşkün olmayan "Güzel bir elbise, pahalı bir çanta, marka bir ayakkabı için erkeklerle düşüp kalkan” (Ümit 2019, 107) kadınlardan farklıdır. Bu ilk sorguda Gülseren’i saygın ve namuslu olarak tanımlayan Hasan daha önce de tartışıldığı gibi katil olduğu anlaşıldığında Gülseren ile ilgili tam tersi bir resim çizer. Son sorguda Hasan, Gülseren'in çocuğu aldırmak istemediğini, ona bir ev açmak istediğinde buna karşı çıkıp kendisiyle evlenmesi için zorladığını iddia eder. Hasan'a göre Gülseren Hasan'ı kullanmıştır Gülseren'in gözü de Hasan'ın parasındadır.

Hem Zeko'nun hem de Hasan'ın kullandığı dil her ne kadar sadece Gülseren'i hedef almış gibi görünse de aslında bütün kadınları baskılayan ve genel olarak kadınlara karşı düşmanlık ifade eden bir dildir. Kadın düşmanı söylemin nefret söylemi olarak kabul edilmesi gerektiğini savunan Richardson-Self kadın düşmanı söylemi iki kategoride inceler. Birinci kategori bir grup olarak bütün kadınlara karşı takınılmış düşmanca tavrı

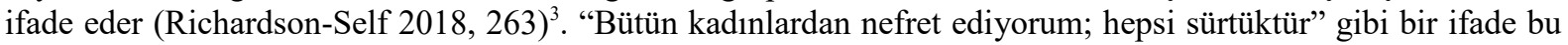
kategoride yer alır (Richardon-Self 2018, 264). Diğer kategoride ${ }^{4}$ ise söylem kadınlar arasındaki bazı kadınları hedef olarak seçer ve düşmanca ifadeler bu kadınlar için kullanılır. Bu durumda kadın düşmanı söylem "kötü kadınlar" ve "iyi kadınlar" arasında bir ayırım yaptırmaya odaklanır ancak yazar bu ikinci kategorinin de bütün kadınları baskı altına aldığını söyler (Richardson-Self 2018, 265-266). Bunun nedeni ise kadınlar, ne kadar zor olursa olsun, "kötü kadın" yaftasını yememek için hep "iyi kadın” olmaya çalışacak ama kadın olmaları sebebiyle her zaman bazı erkekler ve bazı kadınlar tarafından "kötü kadın” olarak görülme riski altında olacaklardır (Richardson-Self 2018, 266). Dolayısıyla kadın düşmanı söylem her iki durumda da kadınları baskı altına alacaktır. İşte bu noktada Zeko'nun Gülseren'i “rahat bir kızdı” diye tanımlayıp “Gülseren gibi kadınlar, adamı kolayca katil edebilir” (Ümit 2019, 119) demesi Gülseren’i “kötü kadın” kategorisine koyarak Gülseren'in düştüğü durumu ona "müstahak" olarak gördüğünün ifadesidir ki bu söylem "kötü kadın" olmak istemeyen diğer bütün kadınlar için bir gözdağı niteliğindedir. Benzer şekilde Hasan’ın Gülseren'i “düzgün” bir kadın olarak tanımladığı ve Gülseren'i övmeye çalıştı̆̆ı ilk sorgusunda "kötü kadınları" tanımlamak için kullandığı “erkeklerle düşüp kalkan" kadınlar ifadesi de kadınlar arasında ayırım yapan ve yine kadın düşmanı ve nefret söylemi içeren bir konuşmadır. Dolayısıyla Gülseren'in eski sevgilisi Zeko ve katili Hasan hikâye boyunca sergiledikleri erkekliklerle paralel bir söylem üretmektedirler. Hatırlanacağı gibi Zeko tahakkümcü ve toksik 
erkeklikler sergilerken Hasan da kadına uygulanan şiddetin sebebinin kadının kendisi olduğunu temsil eden eril düşünce şeklini sembolü olarak hikâyede yer almaktadır.

$\mathrm{Bu}$ iki karakterin sergiledikleri erkeklikler göz önüne alınınca kullandıkları kadın düşmanı söylem ilginç görünmeyebilir ancak hem hikâyenin anlatıcısı hem kahramanı hem de olumlu erkeklikler sergileyen karakteri Nevzat'ın Gülseren'e atıfta bulunurken "kız" kelimesini kullanması ilgi çekicidir. Birkaç örnek verilebilir: "bir kez daha süzdüm yerde yatan kızı" (Ümit 2019, 107), "Kızı taciz etmişsin” (Ümit 2019, 120), "k1z boşa ölmemiş mi olacaktı" (Ümit 2019, 130), "Eğer kı hamileyse” (Ümit 2019, 141), “o k1z1 siz öldürdünüz" (Ümit 2019, 147). Her ne kadar olumlu erkeklikler sergilese de, niyeti kötü olmasa da Gülseren’i kastetmek için Nevzat'ın kullandığ 1 “kız” kelimesi, Richardson-Self'in tanımı bağlamında, cinsiyetçi bir söylem olarak kabul edilebilir. Richardson-Self bir erkeğin pek de düşünmeden, herhangi bir kötü niyet gütmeksizin yetişkin bir kadına kadın demeyip özellikle "kız" demesi örneğine odaklanır ve böyle bir konuşma pratiğinin kadınların erkeklerden daha düşük statüde olduklarının ima edilmesidir der (Richardson-Self 2018, 263). Dolayısıyla hikâyede olumlu erkeklikler sergileyen Nevzat'ın Gülseren'e atıfta bulunurken cinsiyetçi bir söylem kullandığı söylenebilir. Richardson-Self'in de belirttiği gibi cinsiyetçi söylem düşmanlık içermeyebilir (Richardson-Self 2018, 261) ki Nevzat'ın söylemi de düşmanca değildir, hatta Nevzat kadın düşmanlığının karşısında durur ancak buna rağmen Nevzat'ın kullandığg dil de cinsiyetçi bir anlam ifade eder. Buna ek olarak evlilik öncesi kadına kız deyip kadının kadınlığını ve toplum içindeki statüsünü evlilik ve dolayısıyla bir erkekle bedensel temasına indirgeyen anlamları da göz önüne alındığında Nevzat'ın hikâye boyunca Gülseren'i kastetmek için "kız" kelimesini kullanması sorgulamaya değerdir.

Bununla birlikte hikâyenin başlığı "Overlokçu Kız" da cinsiyetlendirilmiş emeğin simgesi olarak okunabilir. Kadın emeğinin tarihçesi bu yazının amacının çok dışında bir konu olsa da Gülseren'in overlokçu kız olarak cinsiyetlendirilmiş iş gücüne tabii kılınmasını açıklayabilmek adına kadınların tekstil endüstrisine dâhil olmaları ve kadın iş gücünün tekstil atölyelerinde nasıl kullanılageldiği bahsedilmeye değer bir noktadır. Geçmişte olduğu gibi bugün de tekstil endüstrisinin yükselişte olduğu gelişen ekonomilerde tekstil fabrikaları kadın iş gücünün ülke ekonomisine resmi olarak katıldığı yerlerdir (English 2013, 68). On dokuzuncu yüzyıl sonlarına doğru Amerika'daki tekstil atölyelerindeki iş bölümünde cinsiyet ayrımı cinsiyetlendirilmiş fiziksel özellikleri iyice pekiştirir; atölye sahiplerinin kadınların çeviklikleri, el çabukluğu ve becerileri ve küçük parmaklarıyla tekstil makinelerine daha çabuk uyum sağlayacaklarına dair inanışları bu cinsiyetlendirilmiş iş gücünü daha da arttırır (English 2013, 70). Otomasyonun gelişmesiyle yüksek beceri gerektirmeyen mekanik işler erkeklerin radarından çıkarken paraya muhtaç kadınların düşük ücrete razı olup para kazanabilecekleri bir alan olarak kalır. Böylece tekstil endüstrisinde erkekler beceri gerektiren ve statü vaat eden model kalıbı çıkarma ya da amirlik gibi pozisyonlara sahip çıkarken kadınlar vasıfsız işlere mahkûm olurlar (English 2013, 70-71). Emeğin bu şekilde dişileştirilip cinsiyetlendirilmesi bu alanlarda çalışan kadınların sayısındaki artışla ilgili olduğu kadar cinsiyet eşitsizliğini yaratan ve yeniden üreten düşünce sistemiyle de ilgilidir (English 2013, 72). Bugünün iş piyasası da geçmişte olduğu gibi kadın ve erkek arasındaki iş gücü ücret farklılıkları ve cinsiyet temelli ayırımcılıkla şekillenirken kadın iş gücüne talep beceri gerektirmeyen ve kariyer geliştirme şansı olmayan alanlarda toplanmıştır (English 2013, 72). Bu noktada elimizdeki hikâyede eril tahakkümün sarmalından kurtulamayan Gülseren'in tekstil atölyesinde overlokçu kız olarak çalışması anlamlıdır. Gülseren kariyer hayali bile kuramayacağı bir pozisyonda mekanik ve yüksek beceri gerektirmeyen ve de cinsiyetine "uygun" bir işte çalışmaktadır. Yaptığı işin kendisi Gülseren'in tekstil atölyesindeki yerini de simgeler niteliktedir. Overlok sözlükte tanımlandığı gibi "Kumaş, halı, kilim vb.nin kenarına makine ile yapılan sıkı, zikzaklı dikiş”tir (Türk Dil Kurumu Sözlükleri 2019). Overlok yapmak kumaşın en kenarının iplik iplik olmasına engel olmak için ortaya konan emeğin adıdır. Bir kumaş parçasının yaratıcı bir şekilde tasarlanıp kesilip biçilip yepyeni bir şekle sokulup yeni kullanım değeri kazandırıldığı sürece dâhil olamadan sadece kumaşın kenarına dikiş yapmaktan ibaret olan işiyle Gülseren tekstil atölyesinde de en kenardaki, en dıştakidir. Dolayısıyla hikâyenin başlığı olarak kullanılan “Overlokçu Kız” ifadesi Gülseren’in cinsiyetlendirilmiş iş gücünün ve erkek egemen toplumda eşitsiz toplumsal cinsiyet ilişkilerinin zihinlerdeki yansımasıdır. Yukarıda da tartışıldığı gibi "kız" kelimesinin barındırdığı anlamlar, overlokçuluk işinin doğası ve de kadının tekstil endüstrisindeki tarihsel yeri düşünüldüğünde overlokçu kız ifadesi erkeğin üstün ve kadının madun olması hali ile ilişkilendirilebilir.

\section{Sonuç}

“Overlokçu Kız” hikâyesi toplumsal cinsiyet ilişkileri bağlamında farklı hiyerarşik örüntüleri resmetmektedir. Gülseren erkek egemen toplumun kadın üstündeki sistematik tahakkümünü simgeler. Erkek kardeşi Gülabi’nin 
sembolik sermayesi olan Gülseren, erkek egemen toplumu sahiplenen ve her firsatta onu yeniden inşa eden ninesi Satı Kadın tarafından gözden çıkarılan torundur. Gülseren'in cansız bedeni dışında hiç görünmediği bu hikâye ironik bir şekilde Gülseren'in etrafında şekillenen eşitsiz toplumsal cinsiyet ilişkilerini resmeder. Hikâye aynı zamanda farklı erkekliklere ve bu erkekliklerin dinamiklerine ayna tutarken eşitsiz toplumsal cinsiyet ilişkilerinin toplumun her katmanına yayılmış olduğunu da gösterir niteliktedir. Çete lideri Zeko, toksik ve tahakkümcü erkekliklerin temsili olarak resmedilirken başkaları üzerinde tahakküm kurma potansiyeli yüksek olan komiser yardımcısı Ali özellikle eşcinsel Serhat'la karşılaştığı anda eşitsiz toplumsal cinsiyet ilişkilerini inşa ederek hegemonik erkeklik örüntüsü içinde yer alır. Gülseren'in katili, tekstil atölyesinin patronu Hasan ise kadına uygulanan şiddeti normalleştirmeye çalışan ve bu şiddetin sorumlusu olarak yine kadını suçlayan eril zihniyetin temsilidir. Başkomiser Nevzat, genelde olumlu erkekliğin resmidir ancak farklı bağlamlarda tahakkümcü ve geçici hegemonik erkeklikler sergiler. Nevzat'ın erkekler ve kadınlarla olan etkileşimlerimde farklı erkeklikler sergilemesi ise toplumsal cinsiyet ilişkilerinin karmaşık, akışkan ve dinamik yapısına işaret eder. Öte yandan "Overlokçu Kız”, kadın cinayetleri ve kadının ezilmişliğine dikkat çekip bu durumu eleştirse de hikâyenin olumlu erkeklikler sergileyen karakteri olan Nevzat'ın geçici hegemonik erkeklik sergilediği diyaloglar ve cinsiyetçi söylem pratikleri ironik bir şekilde hikâyenin bu amacına çelme takar ve eşitsiz toplumsal cinsiyet ilişkilerini yeniden üretir. 
${ }^{1}$ Messerschmidt "erkeklik" kavramını açıklarken onun "bireylerin bedenlerine veya kişilik özelliklerine gömülmüş sabit bir öz" olmadığını, aslında erkekliklerin "toplumsal eylem içinde hayata geçirilen uygulama biçimleri" olduğunu ve bu nedenle de "belirli bir sosyal ortamdaki toplumsal cinsiyet ilişkilerine göre farklılıklar" (Messerschmidt 2019, 70) gösterebileceğinin altını çizer.

${ }^{2}$ Kavramın orijinali “emphasized femininity”dir. Connell'ın Toplumsal Cinsiyet ve İktidar kitabının Türkçesinde "ön plana çıkarılmış kadınlık" olarak geçmektedir. Öte yandan Messerschmidt'in Hegemonik Erkeklik kitabının çevirisinde "vurgulanan kadınlık" ve "vurgulanmış kadınlık" olarak kullanılmıştır.

${ }^{3}$ Yazar çalışmasında bu söylemi "interdivisional misogynistic speech" kavramı ile karşılar.

${ }^{4}$ Yazar çalışmasında bu söylemi de "intradivisional misogynistic speech" kavramı ile karşılar.

\section{Kaynakça}

Bourdieu, Pierre. Eril Tahakküm, Çev. Bediz Yılmaz. (İstanbul: Bağlam Yayınları, 2015).

Carrigan, Tim, Bob Connell ve John Lee. "Toward a New Sociology of Masculinity," Theory and Society 14, no:5 (1985): 551-604, http://www.jstor.org/stable/657315

Connell, Raewyn W. ve James. W. Messerschmidt. "Hegemonic Masculinity: Rethinking the Concept," Gender \& Society 19, no:6 (2005): 829-859, https://doi.org/10.1177/0891243205278639

Connell, Raewyn W. Toplumsal Cinsiyet ve İktidar: Toplum, Kişi ve Cinsel Politika, Çev. Cem Soydemir. (İstanbul: Ayrıntı Yayınları, 2016)

Connell, Raewyn W. Erkeklikler, Çev. Nagihan Konukçu. (Ankara: Phoenix Yayınları, 2019)

English, Beth. "Global Women's Work: Historical Perspectives on the Textile and Garment Industries," Journal of International Affairs 67, no:1 (2013): 67-82, https://www.jstor.org/stable/24461672

hooks, bell. Değişme İsteği: Erkekler, Erkeklik ve Sevgi, Çev. Zeynep Kutluata. (İstanbul: Bgst Yayınları, 2018)

Kara, Zülküf ve Mehmet Ali Uluç. "Şiddetin Cinsiyeti: Bir Modern Toplum Anksiyetesi," e-Şarkiyat İlmi Araştırmalar Dergisi/Journal of Oriental Scientific Research 3, no:25 (2019): 1566-1581, https://doi.org/10.26791/sarkiat.655891

Messerschmidt, James W. Hegemonik Erkeklikler: Formülasyon, Yeniden Formülasyon ve Genişleme, Çev. Eleştirel Erkeklik İncelemeleri İnisiyatifi, Ed. Çimen Günay-Erkol ve Nurseli Yeşim Sünbüloğlu. (İstanbul: Özyeğin Üniversitesi Yayınları, 2019)

Richardson-Self, Louise. "Woman-Hating: On Misogyny, Sexism, and Hate Speech,” Hypatia 33, no: 2 (2018):256-272, https://doi.org/10.1111/hypa.12398

Sancar, Serpil. Erkeklik: İmkânsız İktidar (İstanbul: Metis Yayınları, 2011)

Schippers, Mimi. "Recovering the Feminine Other: Masculinity, Femininity, and Gender Hegemony," Theory and Society 36, (2007): 85-102, https://doi.org/10.1007/s11186-007-9022-4

Türk Dil Kurumu Sözlükleri, “Adam,” Erişim tarihi Temmuz 1, 2020, https://sozluk.gov.tr/

Türk Dil Kurumu Sözlükleri, “Adam gibi,” Erişim tarihi Temmuz 1, 2020, https://sozluk.gov.tr/

Türk Dil Kurumu Sözlükleri, “Kadın,” Erişim tarihi Temmuz 1, 2020, https://sozluk.gov.tr/

Türk Dil Kurumu Sözlükleri, “Overlok,” Erişim tarihi Kasım 10, 2020, https://sozluk.gov.tr/

Türk Dil Kurumu Sözlükleri, “Sümsük,” Erişim tarihi Temmuz 1, 2020, https://sozluk.gov.tr/

Ümit, Ahmet. “Overlokçu Kız,” Aşkımız Eski Bir Roman içinde, 99-150 (İstanbul: Yapı Kredi Yayınları, 2019)

Yüksel-Kaptanoğlu, İlknur. "Erkeklerin Kadına Yönelik Şiddete Bakışı," Türkiye’de Kadına Yönelik Aile Içi Şiddet Araştırması içinde, 225-258 (Ankara: Elma Teknik Basım Matbaacılık, 2015), http://www.hips.hacettepe.edu.tr/KKSA-TRAnaRaporKitap26Mart.pdf 